Tetiana Tkachenko ${ }^{1}$, Dr, Professor of Department of Labour and Environment Protection ORCID ID 0000-0003-2105-5951 e-mail: tkachenkoknuba@gmail.com

Oleksii Tkachenko ${ }^{1}$, student, Department of Architectural Design of Civil Buildings and Structures Head of Sustainability ORCID ID 0000-0003-1536-5208 e-mail: alext654321123456@gmail.com

Olena Voloshkina ${ }^{1}$, Dr, Professor of Department of Labour and Environment Protection ORCID ID 0000-0002-3671-4449 e-mail: e.voloshki@gmail.com

Adam Ujma ${ }^{2}$, Dr. eng. of Faculty of Civil Engineering

ORCID ID 0000-0001-5331-6808 e-mail: adam.ujma@pcz.pl

${ }^{1}$ Kyiv National University of Construction and Architecture, Kyiv, Ukraine

${ }^{2}$ Czestochowa University of Technology, Częstochowa, Poland

\title{
PROSPECTS OF DESIGNING SMALL ARCHITECTURAL FORMS USING ALTERNATIVE ENERGY SOURCES
}

\begin{abstract}
The energy efficiency of the transport system is one of the key issues in the concept of sustainable development of modern cities. Increasing energy efficiency in the transport sector implies increasing the efficiency of the entire transport sector: from modernizing vehicles to introducing energy-efficient comfortable stops for public transport into the city system. One of the problems of modern architecture of large cities is the creation of a unified architecture of small architectural forms $(S A F)$, namely, stops of urban public transport. They should not only have a modern design, but also be comfortable, functional, safe and energy efficient. In the article, the authors propose a unified urban archetype for an energy-efficient public transport stop for the city of Kyiv. Energy efficiency is achieved by installing solar panels on the roofs of the SAF. During the placement of the bus stop, it is imperative to take into account the shading from nearest buildings located on the south, southeast and south-west sides. Depending on the orientation of the roof of the stop to the cardinal points and the type of solar panels, it can generate about $2030 \mathrm{~kW} \cdot \mathrm{h} /$ year (west orientation) - $2269.9 \mathrm{~kW} \cdot \mathrm{h} /$ year (south orientation) of electricity. The maximum deviation from the averaged equal-percentage value $(2143.16 \mathrm{~kW} \cdot \mathrm{h} /$ year) related to the actual data between the maximum and minimum of generation is only $5.55 \%$. This is explained by the angle of photovoltaic panels, which is optimized for universal use. The proposed archetype is energy efficient, functional, and therefore can be taken as a basis for mass placement in the city.

Key words: public transport stop; energy efficiency; solar panels; archetype
\end{abstract}

(C) T. Tkachenko, O. Tkachenko, O. Voloshkina, A. Ujma, 2021

ISSN: 2411-4049. Екологічна безпека та природокористування, № 1 (37), 2021 


\section{Introduction}

Today, energy is the most important driving force of world economic progress. In the middle of the 20th century, energy consumption was growing in all countries of the world. If we look at the structural components of the world energy, we can see that most needs are provided by the use of minerals: coal, oil, natural gas, uranium. This leads to depletion of natural resources. Today environmentalists note that humanity requires 1.75 of planet Earth to provide all needs [1]. This means that people consume so quickly that the planet does not have time to replenish its resources. The UN report "Climate-neutral cities" [2] emphasizes the paramount role of urbocenoses in mitigating the problems associated with climate change. According to experts, $75 \%$ of global energy consumption and $80 \%$ of greenhouse gas emissions fall on cities [2]. The main contribution to the greenhouse effect is made by $\mathrm{CO}_{2}$, which is an indicator of the ecological footprint of urbocenoses. The main contribution to the greenhouse effect is made by $\mathrm{CO}_{2}$, which is an indicator of the ecological footprint of urbocenoses. Despite sharp fluctuations in the concentration of $\mathrm{CO}_{2}$ in the Earth's atmosphere over the past geological period, the natural cycle of $\mathrm{CO}_{2}$ over the past few millennia has not changed.

Anthropogenic activity disturbs this balance due to the release of $\mathrm{CO}_{2}$ bound in such natural carbon storage as fossil fuels and green biomass. With the beginning of the industrial era in the XVIII century, the concentration of $\mathrm{CO}_{2}$ in the atmosphere has increased by almost a third. As a result of these actions over the past century, there has been a global increase in average temperature, followed by global warming.

Reducing $\mathrm{CO}_{2}$ emissions is the main mechanism for slowing down climate changes. In solving this problem, technologies with alternative energy sources are proposed.

In August 2018, the Government of Ukraine adopted the "Strategy for Low Carbon Development until 2050" [2], which provides a gradual reduction in fossil fuel use and the start of investment in renewable energy sources. Therefore, the search and implementation of energy efficient technologies is a priority task.

One method of the reduction $\mathrm{CO}_{2}$ emissions is the use of solar radiation to generate electricity [3-7; 8-12; 13-14].

The energy efficiency of the transport system is one of the key problems in the concept of sustainable development of modern cities [15]. Increasing energy efficiency in the field of transport implies increasing the efficiency of the entire transport sector: from modernizing vehicles to introducing energy-efficient comfortable stops for public urban transport into the urban system [16-18].

Ukraine has developed the "Strategy for Sustainable Development of Ukraine until 2030". One of the operational purposes of the "Strategy" is to create a viable infrastructure, to promote inclusive energy efficient and innovative industrial development [19].

Within the framework of the "Strategy" in the city of Kyiv, the project of the solution of Kyiv "About the consolidated concept of the development of transport stops in the city of Kyiv" [20] was broken up. The project envisages the definition of archetypes of transport stops and the improvement of a single procedure for their placement, arrangement and maintenance. At the same time, city public transport stops should have a modern design; should be compact and functional; should be suitable for all age groups of passengers, taking into account people with disabilities; should be safe; environmentally friendly and energy efficient. 
The idea of creating SAFs using solar panels is not new. For example, London was the first city in the world where TfL (Transport for London) in 2002-2005 tried bus stops with photovoltaic. Later this example was followed by cities in Canada and the USA [21]. Several autonomous stops have even been installed in Kyiv [21-23]. However, there has been no experience of mass construction of such stops.

\section{Materials and Methods}

The purpose of the work is to create a project of municipal transport stop using a renewable energy source (solar photoelectric modules with double glass).

Tasks:

- to calculate the amount of electricity required to provide a stop lightning during the year;

- to create a project of a stop for further mass installation in Kyiv.

Currently, there are more than 2,570 public transport stops in Kyiv. There are for about 1,190 equipped with waiting pavilions, 664 - with stop complexes [24]. Most of them are aesthetically and technically outdated.

It should be noticed that almost all existing stops consume electricity from the electricity grid for lighting at night and heating during winter period. According to the following formula, we calculate the amount of electricity required to illuminate one stop during the year:

$$
W=N \cdot P \cdot \tau \cdot z
$$

where $W$ - amount of electricity required to illuminate one stop during the year (kW/year); $N$ - the number of luminaires at one stop (pcs.); $P$ - the power of one luminaire (W); $\tau-$ the time during that the luminaire consume energy (hours); $z$ - number of working days.

According to calculations, we have approximately $1051 \mathrm{~kW} /$ year for one stop (we take 8 lamps, the power of each of which is $36 \mathrm{~kW}, 8$ hours of operation during 365 days).

According to formula (2) we find the amount of energy consumed by all stops in Kyiv during the year:

$$
W_{\text {general }}=W+a,
$$

where $W_{\text {general }}$ - the amount of electricity consumed by all stops during the year (kW/year); $W$ - the amount of electricity consumed by one stop during the year (kW/year); $a$ - the number of stops in the city of Kyiv (pcs.).

$$
W_{\text {general }}=1051 \cdot 2570=2701070 \mathrm{Kw} / \mathrm{year}
$$

For comparison, according to the method of electricity audit [25] it is established that an apartment of $100 \mathrm{~m}^{2}$ will consume $10-15 \mathrm{~kW}$ of energy per day, which will be 3650-5475 kW per year. All the energy spent on lighting all the capital's bus stops could be provided from 500 to 700 apartments with an area of $100 \mathrm{~m}^{2}$.

To solve the problem of energy consumption of existing stops, a project of the bus stop with photoelectric modules was developed. 
To fully provide an illumination of a stop, the solar module must generate a certain amount of electricity. This number is not constant and depends on a number of factors:

- period of the year and number of sunny days;

- longitude and latitude of the area (in our case we take the city of Kyiv);

- shading from nearest buildings located on the south, southeast, southwest sides;

- location of the object relative to the north-south direction;

- number of luminaires and their power (calculations were performed for LED luminaires with a power of $36 \mathrm{~W}$ ).

Kyiv is located at $50^{\circ} 27^{\prime} 16^{\prime \prime}$ north latitude and $30^{\circ} 31^{\prime} 25^{\prime \prime}$ east longitude.

The time of sunrise and sunset during the year for the city of Kyiv (Fig. 1) varies in such a way that the greatest duration falls on the summer period (16-18 hours per day), and the smallest - respectively on the winter (11-13 hours per day).

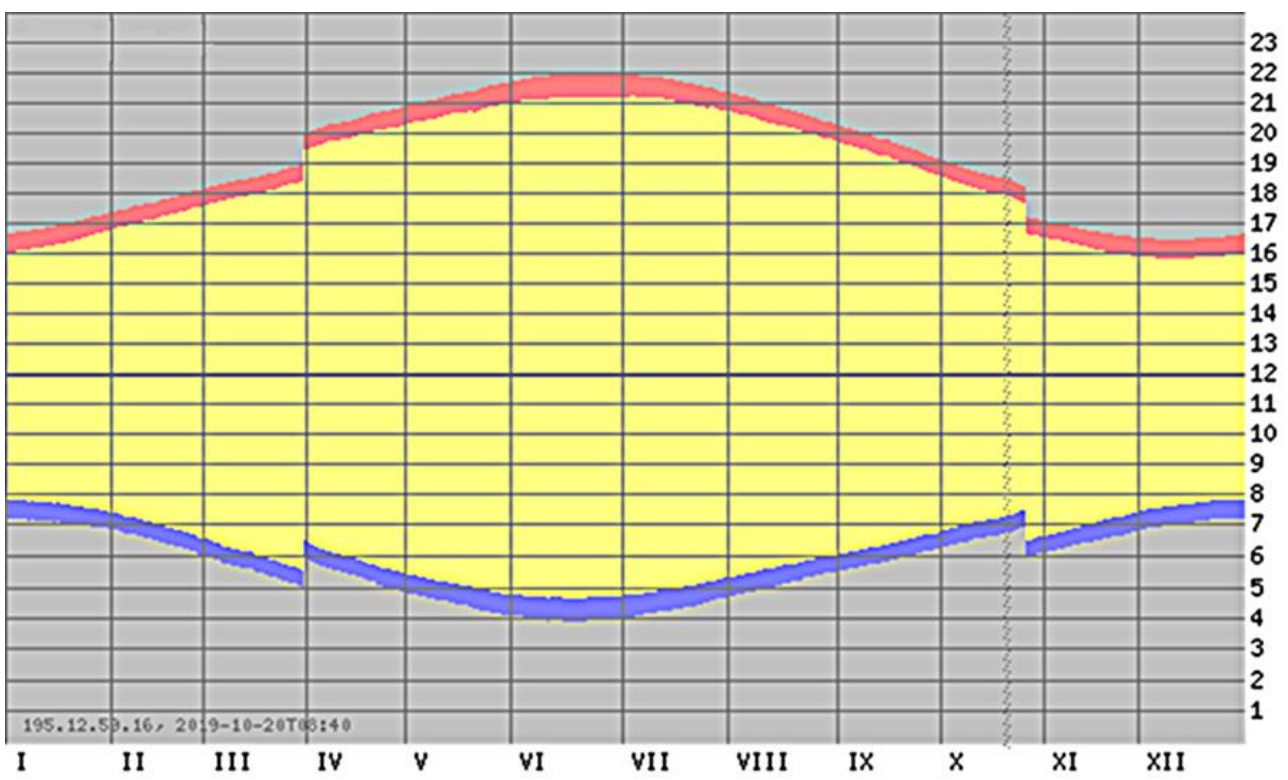

Figure 1 - Day and night duration schedule for Kyiv [26]

- day time; $\quad$ - night time; $\quad$ - sunrise; $\quad$ - sunset

Data about the amount of sunlight that falls per unit area of the surface for the city of Kyiv (Table 1) is accepted according to the current norms in Ukraine [27]. We see that the largest amount of sunlight falls during the period from June to August, the smallest - from December to February. The largest amount of electricity will be produced in the period from May to September in the southern, southeastern and southwestern orientation of the roof (Table 2). Excess electricity can be collected for further use or for recharging gadgets and electric scooters (at the stop there is a parking space for bicycles and scooters). 
Table 1 - Solar radiation gains on a horizontal surface, averaged by month

\begin{tabular}{|c|c|c|c|c|c|c|c|c|c|c|c|c|c|c|}
\hline \multicolumn{3}{|l|}{ Month } & I & II & III & IV & $\mathrm{V}$ & VI & VII & VIII & IX & $X$ & $\mathrm{XI}$ & XII \\
\hline \multicolumn{3}{|c|}{ Days number $n$} & 31 & 28 & 31 & 0 & 1 & 30 & 31 & 31 & 30 & 31 & 30 & 31 \\
\hline \multirow{9}{*}{ 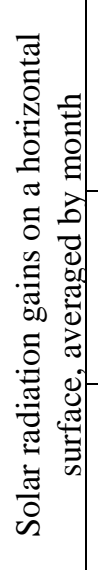 } & \multirow{3}{*}{ 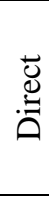 } & $\mathrm{U}$ & 25 & 46 & 100 & 170 & 285 & 300 & 300 & 265 & 170 & 80 & 23 & 15 \\
\hline & & $\mathrm{MJ} /$ & 0.81 & 1.64 & .23 & 5.67 & 9.19 & 10.0 & 9.68 & 8.55 & 5.67 & 2.58 & 0.77 & 0.48 \\
\hline & & $\mathrm{kW}$ & 0.22 & 0.46 & 0.90 & 1.57 & 2.55 & 2.78 & 2.69 & 2.37 & 1.57 & 0.72 & 0.21 & 0.13 \\
\hline & \multirow{3}{*}{ 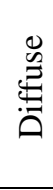 } & $\mathrm{MJ} /($ & 60 & 96 & 170 & 215 & 280 & 290 & 288 & 230 & 168 & 110 & 58 & 44 \\
\hline & & $\mathrm{MJ}$ & 1.94 & 3.43 & 5.48 & 7.17 & 9.03 & 9.67 & 9.29 & 7.42 & 5.60 & 3.55 & 1.93 & 1.4 \\
\hline & & $\mathrm{k}$ & 0.54 & 0.95 & 1.52 & 1.99 & 2.51 & 2.69 & 2.58 & 2.06 & 1.56 & 0.99 & 0.54 & 0.39 \\
\hline & \multirow{3}{*}{ స్ } & $\mathrm{MJ} /$ & 85 & 142 & 270 & 385 & 565 & 590 & 588 & 495 & 338 & 190 & 0 & 9 \\
\hline & & $\mathrm{MJ} /\left(\mathrm{m}^{2} \cdot\right.$ day $)$ & 2.74 & 5.07 & 8.71 & 12.8 & 18.2 & 19.7 & 19.0 & 16.0 & 11.3 & 6.13 & 2.70 & 1.90 \\
\hline & & $\mathrm{kW} \cdot \mathrm{h} /\left(\mathrm{m}^{2} \cdot\right.$ day $)$ & 0.76 & 1.41 & 2.42 & 3.56 & 5.06 & 5.46 & 5.27 & 4.44 & 3.13 & 1.70 & 0.75 & 0.53 \\
\hline
\end{tabular}

Table 2 - Annual amount of produced energy at orientations that cause high effectiveness of energy production

\begin{tabular}{|l|l|}
\hline Roof orientation & $\begin{array}{l}\text { Produced electric energy, } \\
\mathrm{kW} \cdot \mathrm{h} / \mathrm{year}\end{array}$ \\
\hline West & 2030,4 \\
\hline South West & 2171,2 \\
\hline South & 2269,6 \\
\hline South East & 2266,2 \\
\hline East & 2163,7 \\
\hline
\end{tabular}

It is convenient to determine the amount of electricity produced by solar panels in specialized software.

This work uses the Power Calculator program, developed by IBC Solar [28]. It uses standard calculation techniques.

The program requires you to enter the location address of the object, length, width, angle and orientation of the roof. Another possibility is to draw the contours of the roof on the map with the task of the lowest edge and angle of inclination.

\section{Results and Discussion}

Civilization moves from consumer society to sustainable development. The first estimates a man by the amount of consumption, which leads to overconsumption of energy resources, excessive environmental pollution by carbon dioxide and other combustion products, heat, waste etc.

The sustainable development estimates by the amount of resource economy. This causes decrease of environmental pollution sometimes, to the detriment of economic effect. In this case, architecture should be not only aesthetical, but also pragmatic, energy-efficient, environment-friendly, and, if possible, combined with renewable energy generation. 
Small architectural forms are especially perspective in this regard. There are too lot of them in modern cities. Municipal transport stops are especially important for people. Unlike the rest of SAFs, there is no possibility to avoid them. In many old cities, a lot of them are decrepit and need reconstruction. It is important to create an architype of functional and energy-efficient stops of municipal transport.

The authors have developed an archetype of autonomous municipal transport stop. The bus stop has an area of $20 \mathrm{~m}^{2}$. There is a kiosk, a waiting area, an area for bicycles and scooters. The project also provides sockets for charging gadgets.

The stop has a v-shaped roof, each part of which is inclined at an angle of 15 degrees to the horizon (Fig. 2, 3). The autonomy of the stop is achieved by installing solar photovoltaic modules with double glazing and a battery pack for energy storage. It is also possible to install a specialized controller to control the charging process and energy consumption.

The amount of electricity that solar panels will produce depending on the orientation of the roof is given. According to calculations using the Power Calculator program, the largest amount of electricity will be generated in the period from May to September in the south $(2269.6 \mathrm{~kW} \cdot \mathrm{h} /$ year $)$, southeast $(2266.26 \mathrm{~kW} \cdot \mathrm{h} / \mathrm{year})$ and southwest $(2171.2 \mathrm{~kW} \cdot \mathrm{h} /$ year $)$ roof orientation.

The averaged equal-percentage value related to the actual data between the maximum and minimum of generation (Table 2) is

$$
2 \cdot 2030.4 \cdot 2269.6 /(2030.4 \cdot 2269.6)=2143.16 \mathrm{~kW} \cdot \mathrm{h} / \text { year }
$$

The maximum deviation is only $5.55 \%$. This is explained by the angle of photovoltaic panels, which is optimized for universal use.

The architype is recommended for wide introduction in modern cities and towns to rise energy efficiency and provide sustainable development of urbocenoses.

\section{Conclusion}

The completed stop project contributes to the sustainable development of cities, including the following benefits:

- aesthetic appeal due to modern design and new technologies;

- autonomy and energy independence (due to the installation of solar photovoltaic modules with double glazing and a battery pack for energy storage);

- environmental friendliness. Solar panels use alternative sources (sunlight) as a source of heat. Due to this, they are environmentally friendly and safe;

- security. The lighted stop in the evening is a safe place to wait for public transport, storage of bicycles and scooters;

- comfort. The project of stopping public transport with the use of alternative energy sources makes it possible to create more comfortable living conditions for people of different ages and different physical abilities at this facility;

- due to the listed advantages, the proposed project can be taken as a basis for creating a common architecture for public transport stops for the Kyiv city. 


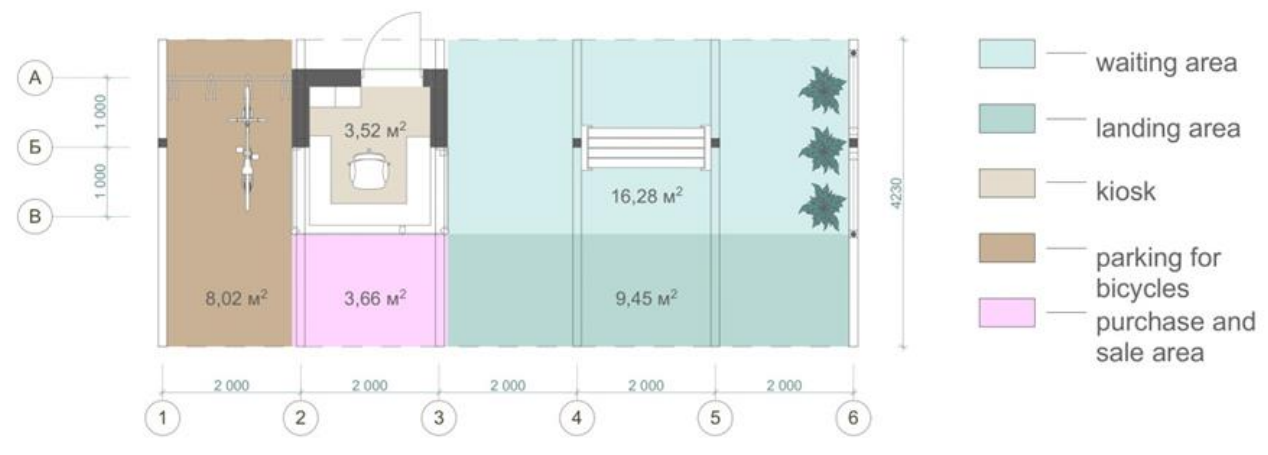

a

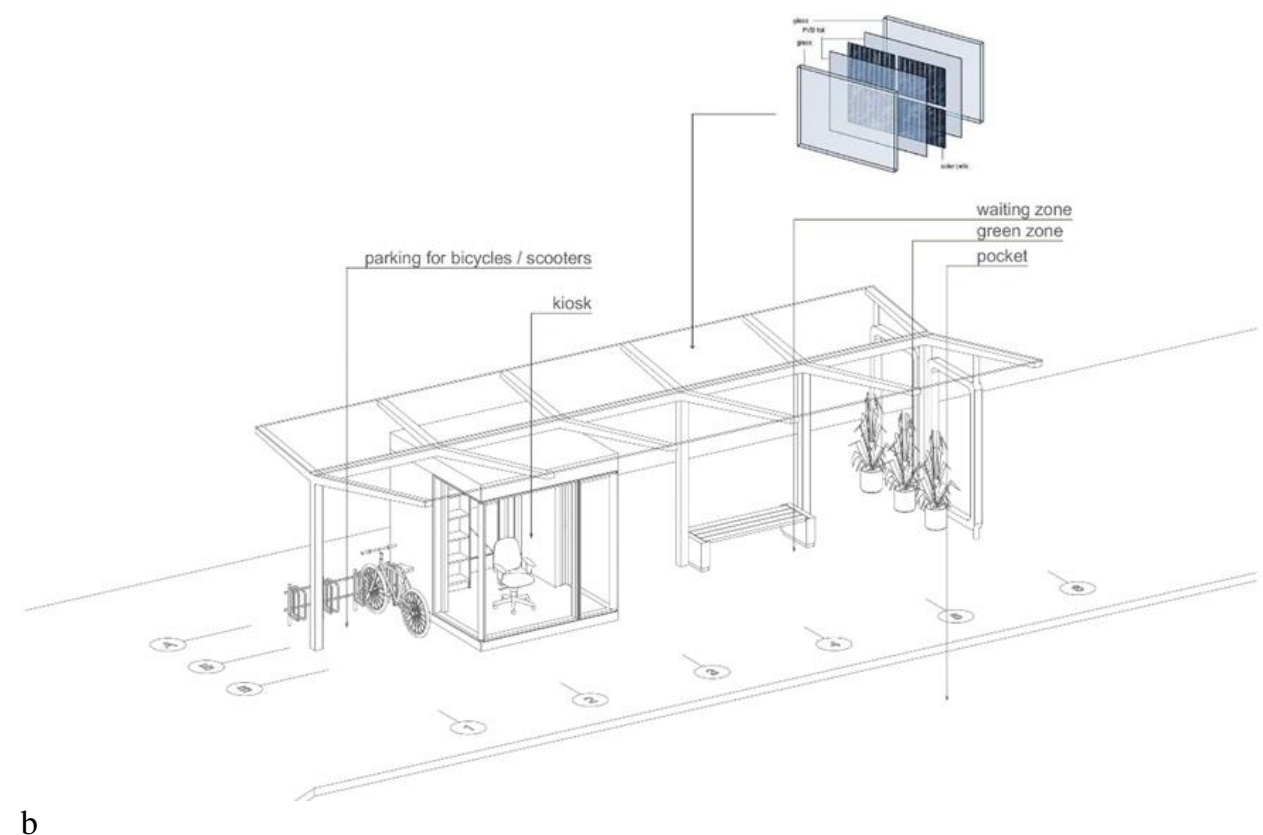

Figure 2 - drawings of the stop:

$\mathrm{a}$ - stop plan with location of functional areas;

$\mathrm{b}$ - general view of the stop

with functional areas and solar panels 


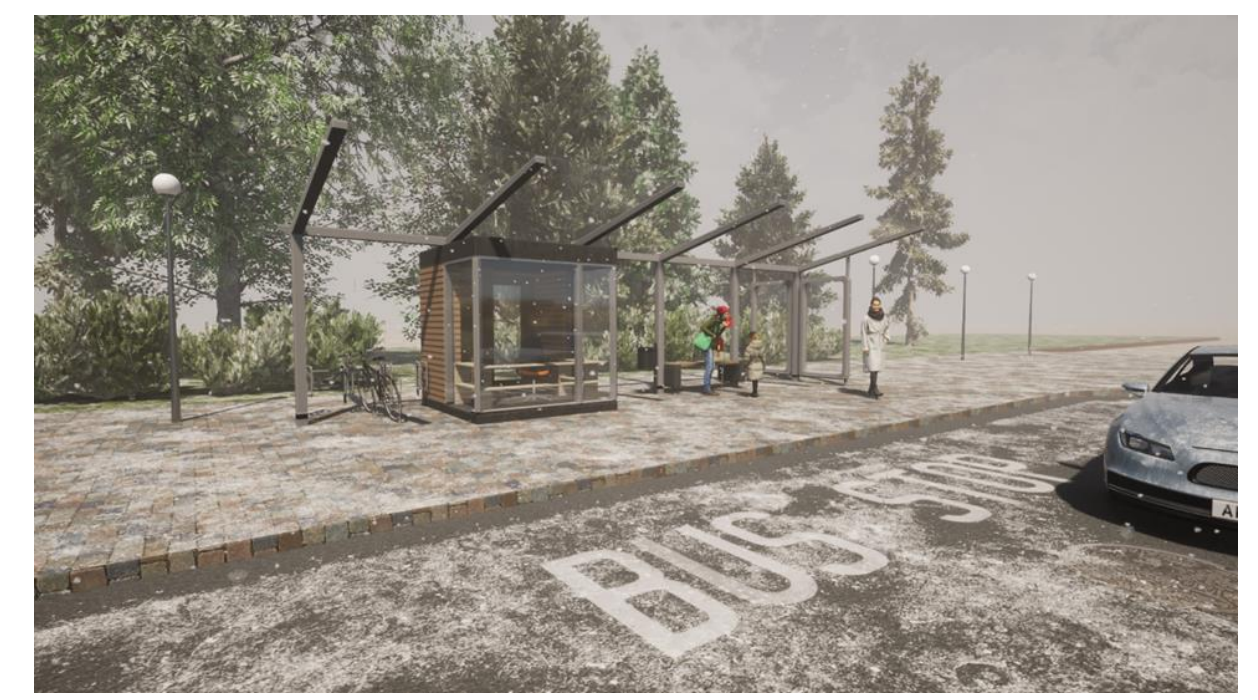

a

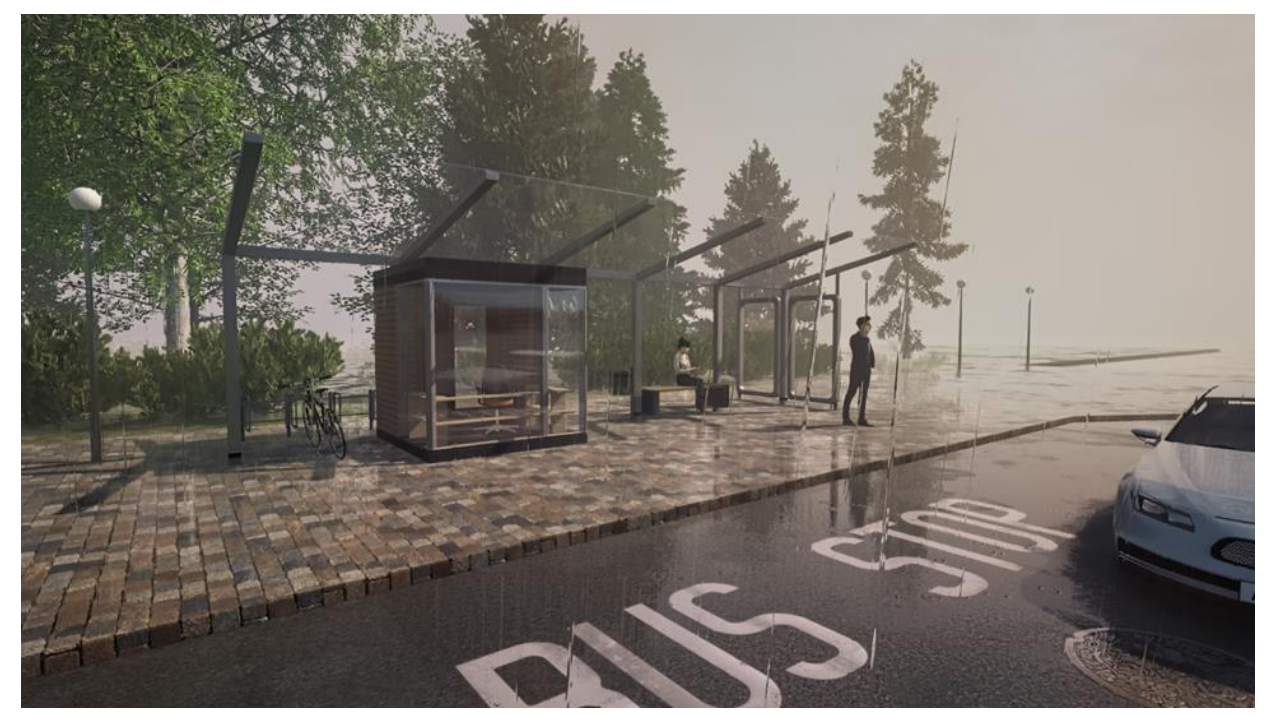

b

Figure 3 - Visualization of the bus stop: a - autumn-winter period;

$\mathrm{b}$ - spring-summer period

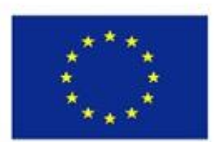

\section{Co-funded by the Erasmus+ Programme of the European Union}

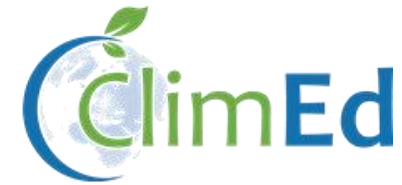

The publication was prepared in the framework of project «Multilevel Local, Nationand Regionwide Education and Training in Climate Services, Climate Change Adaptation and Mitigation 619285-EPP-1-2020-1-FI-EPPKA2-CBHE-JP». The European Commission's support for the production of this publication does not constitute an endorsement of the contents, which reflect the views only of the authors, and the Commission cannot be held responsible for any use which may be made of the information contained therein. 


\section{REFERENCES}

1. Earth Overshoot Day 2019 is July 29th, the earliest ever. (2019). Retrieved 02.10.2020 from: https://www.footprintnetwork.org/2019/06/26/press-release-june-2019-earth-overshoot-day/

2. Strategy of low-carbon development of Ukraine until 2050. (2017). Retrieved 02.10.2020 from: https://menr.gov.ua/files/docs/\%D0\%9F\%D1\%80\%D0\%BE\%D0\%B5\%D0\%BA\% D1\%82\%20\%D0\%A1\%D1\%82\%D1\%80\%D0\%B0\%D1\%82\%D0\%B5\%D0\%B3\%D1\%96 $\% \mathrm{D} 1 \% 97 \% 20 \% \mathrm{D} 0 \% \mathrm{BD} \% \mathrm{D} 0 \% \mathrm{~B} 8 \% \mathrm{D} 0 \% \mathrm{~B} 7 \% \mathrm{D} 1 \% 8 \mathrm{C} \% \mathrm{D} 0 \% \mathrm{BA} \% \mathrm{D} 0 \% \mathrm{BE} \% \mathrm{D} 0 \% \mathrm{~B} 2 \% \mathrm{D} 1$ \%83\%D0\%B3\%D0\%BB\%D0\%B5\%D1\%86\%D0\%B5\%D0\%B2\%D0\%BE\%D0\%B3\%D0\% BE\%20\%D1\%80\%D0\%BE\%D0\%B7\%D0\%B2\%D0\%B8\%D1\%82\%D0\%BA\%D1\%83\%20 \%D0\%A3\%D0\%BA\%D1\%80\%D0\%B0\%D1\%97\%D0\%BD\%D0\%B8\%20.pdf.

3. Sambor, D.J., Wilber, M., Whitney E., \& Jacobson, M.Z. (2020). Development of a Tool for Optimizing Solar and Battery Storage for Container Farming in a Remote Arctic Microgrid. Energies, 13(5143), 5143.

4. Gira, N., \& Dahiya, A.K. (2020). Solar PV-BES in distribution system with novel technique for DC voltage regulation. Engineering Science and Technology, an International Journal, 23(5), 1058-1067.

5. Jbari, Y., \& Abderafi, S. (2020). Parametric study to enhance performance of wastewater treatment process, by reverse osmosis-photovoltaic system. Applied Water Science, 10(10), 1-14. 6. Jou, H.-L., Wu, J.-C., Zhang, T.-Y., \& Shih, S.I. (2020). New power conversion topology for battery-less PV generation system with the functions of grid-connection and isolated grid. Engineering Science and Technology, an International Journal, 23(5), 1074-1083.

7. Lorenzo, C., Narvarte, L., \& Cristóbal, A.B. (2020). A Comparative Economic Feasibility Study of Photovoltaic Heat Pump Systems for Industrial Space Heating and Cooling. Energies, 13(4114), 4114.

8. Prem, P., Sivaraman, P., Sakthi Suriya Raj, J.S., Jagabar Sathik, M., \& Almakhles, D. (2020). Fast charging converter and control algorithm for solar PV battery and electrical grid integrated electric vehicle charging station. Automatika, 61(4), 614-625.

9. Senthil, S. (2020). Effect of charging of phase change material in vertical and horizontal rectangular enclosures in a concentrated solar receiver. Case Studies in Thermal Engineering, $21,100653$.

10. Shaqour, A, Farzaneh, H., Yoshida, Y., \& Hinokuma, T. (2020). Power control and simulation of a building integrated stand-alone hybrid PV-wind-battery system in Kasuga City, Japan. Jurnal Energy Reports, 6, 1528-1544.

11. Sikder, P.S., \& Pal, N. (2020). Modeling of an intelligent battery controller for standalone solar-wind hybrid distributed generation system. Journal of King Saud University: Engineering Sciences, 32(6), 368-377.

12. Sinambela, M., Situmorang, M., Tarigan, K., Humaidi, S., \& Rahayu, T. (2020). Design of solar power system for the new mini region of broadband seismometer shelter in Tiganderket, Karo, North Sumatera, Indonesia. Journal Case Studies in Thermal Engineering, 22, 100747.

13. Sobol, Ł., \& Dyjakon, A. (2020). The Influence of Power Sources for Charging the Batteries of Electric Cars on $\mathrm{CO}<\mathrm{sub}>2</ \mathrm{sub}>$ Emissions During Daily Driving: A Case Study from Poland. Energies, 13(4267), 4267.

14. Wei, Li, Jikang, Li, Zhenzhong, Hu, Sunwei, Li, \& Chan P.W. (2020). A Novel Probabilistic Approach to Optimize Stand-Alone Hybrid Wind-Photovoltaic Renewable Energy System. Energies, 13(4945), 4945.

15. Voloshkina, O., Tkachenko, T., Sipakov, R., \& Tkachenko, O. (2019). The estimation and reduction of risks cauced by air pollution in cities. Budownictwo o zoptymalizowanym Potencjale energetycznym [Construction of optimized energy potential], 8(2), 17-25. https://doi.org/10.17512/bozpe.2019.2.02

16. Beler-Bedecker, S., \& Huyging, H. (2013). Urban transport and energy efficiency. Retrieved 05.10.2020 from: http://greenlogic.by/content/files/dad357e3aecd74d42c89c14 e4d4fb872.pdf 
17. Tkachenko, T., Mileikovskyi, V., \& Ujma, A. (2018). Field Study of Air Quality Improvement by a "Green Roof" in Kyiv. In R. Ulewicz \& R. R. Nikolic (Eds.), 7th International Conference System Safety: Human - Technical Facility - Environment (CzOTO 2018) (pp. 419-424). Warszawa: De Gruyter. doi:https://doi.org/10.2478/czoto-2019-0054 18. Itriashvili, L., Iremashvili, I., Khosroshvili, E., Ujma, A. (2018). Noviy mnogocelevoy polimernyj kompozit i oblasti jego primenenia. Budownictwo o zoptymalizowanym potencjale energetycznym, 1(21), 77-82.

19. Strategy of sustainable development of Ukraine until 2030 (project-2017). Retrieved 05.10.2020 from: file:///C:/Users/\%D0\%A2\%D0\%B0\%D1\%82\%D1\%8C\%D1\%8F\%D0\% BD\%D0\%B0/Downloads/UNDP_Strategy_v06-optimized.pdf.

20. Draft decision of the Kyiv City Council "About the approval of the Concept of placement of public transport stops in Kyiv". (2019). Retrieved 05.10.2020 from: https://kga.gov.ua/rss/200-proekt-rishennya-kijivradi-pro-zatverdzhennya-kontseptsijirozmishchennya-zupinok-gromadskogo-transportu-v-m-kievi

21. Bus boffins solar stops even work in UK winter, 2005. Retrieved 05.10.2020 from: https://tfl.gov.uk/info-for/media/press-releases/2005/september/bus-boffins-solar-stopseven-work-in-uk-winter.

22. Kyivpastrans. (2016). Retrieved 05.10.2020 from: https://ecotechnica.com.ua/ arkhitektura/975-kiev-obzavelsya-umnoj-ostanovkoj-na-solnechnykh-panelyakh.html

23. BG Solar panels have appeared in Kyiv. (2017). Retrieved 05.10.2020 from: https://bzh.life/gorod/v-kieve-poyavilis-ostanovki-s-solnechnymi-batareyami.

24. Kulesh, S. (2015). Kiev public transport stops will be equipped with Wi-Fi and phone chargers. Retrieved 05.10.2020 from: https://itc.ua/news/kievskie-ostanovkiobshhestvennogo-transporta-osnastyat-wi-fi-i-zaryadkami-dlya-telefonov/.

25. Guide: how to audit electricity in a private home or with your own hands. (2015). Retrieved 05.10.2020 from: http://term.od.ua/blog/rukovodstvo-audit-elektroenergii-vchastnom-dome-svoimi-rukami/.

26. Kiev, Ukraine - Sunrise, sunset, dawn and dusk times, table. (2020). Retrieved 05.10.2020 from: https://www.gaisma.com/en/location/kiev.html.

27. Construction climatology. DSTU-N B B.1.1-27: 2010. (2011). Ukraine, Kyiv.

28. Solar Power Calculator. Retrieved 05.10.2020 from: https://powercalculator.ibc-solar.com/.

The article was received 22.09.2020 and was accepted after revision 17.12.2020

\section{Т. Ткаченко, О. Ткаченко, О. Волошкіна, А. Уйма}

\section{ПЕРСПЕКТИВНІСТЬ ПРОЕКТУВАННЯ МАЛИХ АРХІТЕКТУРНИХ ФОРМ З ВИКОРИСТАННЯМ АЛЬТЕРНАТИВНИХ ДЖЕРЕЛ ЕНЕРГІЇ}

Анотація. Енергоефективність транспортної системи $є$ одним із ключових питань концепції сталого розвитку сучасних міст. Підвищення енергоефективності у транспортному секторі передбачає підвищення ефективності всього транспортного сектору: від модернізації транспортних засобів до впровадження енергоефективних комфортабельних зупинок для громадського транспорту в міську систему. Однією з проблем сучасної архітектури великих міст є створення єдиної архітектури малих архітектурних форм (МАФ), а саме, - зупинок міського громадського транспорту. Вони повинні мати не тільки сучасний дизайн, але й бути зручними, функціональними, безпечними та енергоефективними. У статті автори пропонують уніфікований міський архітип для енергоефективної зупинки громадського транспорту для міста Києва. Енергоефективність досягається встановленням сонячних панелей на дахах МАФ. Під час розміщення зупинки обов'язково враховувати затінення від найближчих будівель, розташованих на південній, південно-східній та південно-західній сторонах. Залежно від орієнтації даху зупинки на основні точки та типу сонячних панелей, вона може виробляти близько 2030 кВт·год/рік (орієнтація на захід) - 2269,9 кВт·год/рік (орієнтація на південь) електроенергії. Максимальне відхилення від усередненого рівнопроцентного значення $(2143,16$ кВт·год/рік), що стосується фактичних даних між 
максимумом та мінімумом генерації, становить лише 5,55\%. Це пояснюється кутом нахилу фотоелектричних панелей, який оптимізований для універсального використання. Запропонований архітип є енергоефективним, функціональним, а отже, його можна взяти за основу для масового розміщення в місті.

Ключові слова: зупинка громадського транспорту; енергоефективність; сонячні панелі; архітип

Стаття надійшла до редакиії 22.09.2020 і прийнята до друку після рецензування 17.12 .2020

Ткаченко Тетяна Миколаївна

доктор технічних наук, кандидат біологічних наук, професор кафедри охорони праці та навколишнього середовища Київського національного університету будівництва та архітектури

Адреса робоча: 03037 Україна, м. Київ, проспект Повітрофлотський, 31

ORCID ID 0000-0003-2105-5951 e-mail: tkachenkoknuba@gmail.com

\section{Ткаченко Олексій Андрійович}

студент кафедри архітектурного проектування цивільних будівель і споруд Київського національного університету будівництва і архітектури

Адреса робоча: 03037 Україна, м. Київ, проспект Повітрофлотський, 31

ORCID ID 0000-0003-1536-5208 e-mail: alext654321123456@gmail.com

\section{Волошкіна Олена Семенівна}

доктор технічних наук, професор кафедри охорони праці та навколишнього середовища Київського національного університету будівництва та архітектури

Адреса робоча: 03037 Україна, м. Київ, проспект Повітрофлотський, 31

ORCID ID 0000-0002-3671-4449 e-mail: e.voloshki@gmail.com

\section{Уйма Адам}

кандидат технічних наук, викладач кафедри інженерії будівельних процесів Ченстоховської політехніки

Адреса робоча: Польща, м. Ченстохова

ORCID ID 0000-0001-5331-6808 e-mail: adam.ujma@pcz.pl 